8. Юрьева, Л.Н. (2004) Профессиональное выгорание у медицинских работников. Формирование профилактика коррекция. Издательство «Сфера». Киев. С. 34-49, 242-254

DOI https://doi.org/10.30525/978-9934-588-81-5-2.10

\title{
ОСНОВНІ МЕХАНІЗМИ ОРГАНІЗАЦІЇ ЛОГІСТИКИ УПРАВЛІННЯ В СУЧАСНОМУ МЕДИЧНОМУ ЗАКЛАДІ
}

Коломоєць А. В.

кандидат медичних наук, директор

«Mедсервісгруп»

Михальчук В. М.

доктор медичних наук, професор, заслужений прачівник охорони здоров'я України, завідувач кафедри управління охороною здоров'я Національна медична академія післядипломної освіти імені П. Л. Шупика

Толстанов О. К.

доктор медичних наук, професор, професор кафедри управління охороною здоров'я Національна медична академія післядипломної освіти імені П. Л. Шупика

Гбур 3. В.

доктор наук з державного управління, професор кафедри управління охорони здоров'я

Національна медична академія післядипломної освіти імені П. Л. Шупика м. Київ, Украӥна

Ефективне функціонування охорони здоров'я сприяє зниженню захворюваності, зростанню продуктивності праці, продовженню працездатного періоду та вносить вагомий внесок в економіку - росту національного доходу, підвищенню добробуту населення та якості життя. Даний процес відбувається завдяки впровадженню ефективних медичних технологій та сучасних методів управління. Сьогодні це вкрай важливо, так як перед перед системою охорони здоров'я поста- 
влене завдання пошуку додаткових джерел фінансування та їх ефективного використання, що обумовлює впровадження нових методів та методик управління, заснованих на підході логістики.

Сучасні системні і процесні підходи до управління зазнали значних змін також і в управлінні медичними установами, застосовуючи нові методи і технології управління ресурсами, які базуються на концепції логістики. Позитивними сторонами логістичних технологій в установах охорони здоров'я є: можливість впливу на стратегію і тактику діяльності установ охорони здоров'я, формування нових конкурентних ринкових переваг в даному сегменті ринку. Використання методів і технологій логістики оптимізує процеси за показниками входу інформації про обсяги споживаних ресурсів, іiі отримання та передачі інформації, підвищуючи таким чином якість надання медичної допомоги. Причому логістична підсистема окремо взятого медичного закладу вбудовується в систему ресурсозабезпечення окремого закладу охорони здоров'я в цілому $[1,2]$.

Однак, в науковому середовищі така тема не знайшла належного відображення.

Логістика в сучасному закладі охорони здоров'я може бути використана на макро- та мікрорівні. На макрорівні вона знаменує перехід від управління об'єктами до управління процесами, розглядаючи при цьому взаємодію системи охорони здоров'я $з$ державою та суспільством в цілому, а також з іншими галузями національної економіки. Такий рівень управління передбачає універсальні закони політичного та соціально-економічного устрою суспільства, генеральні принципи здійснення статутної діяльності медичних організацій в існуючій економічній системі. Таким чином, макрологістика вирішує питання, які пов'язані з аналізом якості медичних послуг, створенням загальних методичних рекомендацій, організацією інформаційного процесу, раціональних напрямів матеріальних потоків.

В рамках логістичного підходу організацію охорони здоров'я розглядають, як систему, що увібрала у себе безліч пов'язаних між собою процесів, кінцевою метою яких $\epsilon$ надання якісних медичних послуг. Основна ідея логістичного процесу - це створення певного результату 3 наявних у медичному закладів ресурсів. Слід зазначити, що сьогодні в переході до логістичного управління зацікавлені підприємства різних галузей господарства. Під час медичної реформи в Україні було створено Національну служба здоров'я України, яка $є$ центральним органом виконавчої влади, діяльність якого спрямована на реалізацію державної політики у сфері державних фінансових гарантій медично- 
го обслуговування жителів країни за програмою медичних гарантій. НСЗУ є національним страховиком, який укладає договори з медичними установами та закуповує у них послуги з медичного обслуговування населення. Служба контролює дотримання умов договорів та робить прямі виплати закладам за надані послуги. Міністерство охорони здоров'я України є головним органом у системі центральних органів виконавчої влади, що забезпечує формування та реалізує державну політику у сфері охорони здоров'я, а також захисту населення від інфекційних хвороб, забезпечує формування та реалізує державну політику у сферах епідеміологічного нагляду (спостереження); розвитку медичних послуг; впровадження електронної системи охорони здоров'я, забезпечення державних фінансових гарантій медичного обслуговування населення (НСЗУ); технічного регулювання медичних виробів; забезпечення населення якісними, ефективними та безпечними лікарськими засобами; розвитку кадрового потенціалу системи охорони здоров'я, вищої медичної, фармацевтичної освіти та науки.

Більшість зарубіжних вчених солідарні в думці, що для реалізації переходу до логістичного підходу в охороні здоров'я організаціям не вистачає необхідної теоретичної та практичної бази, достатнього позитивного досвіду впровадження.

Перевагою логістичного підходу в охороні здоров'я $є$ можливість впливати на стратегію і тактику роботи медичної організаціі, на створення нових конкурентних переваг на ринку медичних послуг. Застосування логістики прискорює процеси отримання та передачі інформації про необхідні ресурси в результаті, підвищуючи якість надання медичних послуг. Таким чином, логістика координує діяльність ресурсозабезпечення всієї організації охорони здоров'я в цілому (рис. 1).

Ресурсна логістика розглядається як складова частина сучасного стратегічного планування [3]. Структура стратегічного плану являє собою безліч узгоджених і взаємопов'язаних стратегій за різними напрямками діяльності організації охорони здоров'я, що принципово відрізняється від простих довгострокових планів. Складений установою стратегічний план відрізняється здатністю оперативного реагування на мінливе зовнішне і внутрішнє середовище організації. При стратегічному плануванні використовується стратегічний підхід до цілепокладання і програмно-цільового підходу до досягнення мети, а також рішення задач. Програмно-цільовий метод - це такий собі інструмент стратегічного планування, який здатний забезпечувати механізми розробки конкретних заходів по досягненню мети. Таким 
чином стратегічний план включає в себе систему взаємопов'язаних основних і забезпечуючих програм. Формування системи стратегічного управління потребує також значної перебудови самої системи управління за наступними напрямками:

- ділові управлінські процеси (процедури управління);

- організаційні розподільні структури (розподіл повноважень);

- «образ мислення» і поведінка керівників та співробітників (переорієнтація з формального виконання доручень на досягнення стратегічної мети) тощо.

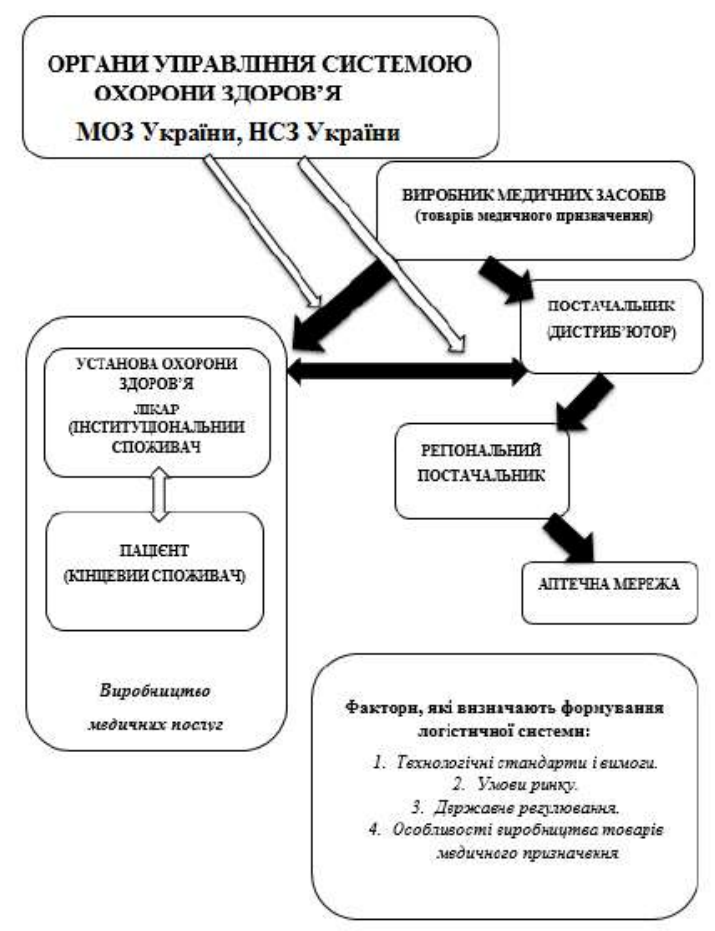

Рис. 1. Логістика у закладах охорони здоров'я Джерело: опрачьовано та сформовано автором

При організації та наданні якісних медичних послуг логістичний підхід - це розгалужена система взаємодії різних служб, інтегровані результати роботи яких дає оптимальну організацію та надання паціє48 
нтам кваліфікованої медичної допомоги. У подальшому, спираючись на застосування інноваційного підходу до логістики у медичній сфері, 3'являється можливість створити контрольоване та регульоване середовище $з$ метою ефективного виконання різноманітних логістичних процесів у сфері охорони здоров'я i, таким чином, підвищувати певні показники регіонального розвитку.

\title{
Література:
}

1. Аранович Л.М., Рогоцкая Н.Д. Логистические подходы к ресурсному обеспечению ЛПУ. Бюллетень медицинских интернетконференциий. 2013. Т. 3. № 3. С. 617.

2. Смірнова В. Л., Панчишин Н. Я. Роль керівників охорони здоров'я в іiі реформуванні. Вісник соц. гігієни та орг. охорони здоров'я Украӥни. 2013. № 3. С. 26-28.

3. Рабаданова М.Р. Стратегическое планирование в системе управления учреждением здравоохранения. Apriori. серия: естественные и технические науки. 2013. № 1. С. 26.

DOI https://doi.org/10.30525/978-9934-588-81-5-2.11

\section{ПОРІВНЯЛЬНИЙ АНАЛІЗ СТРУКТУРИ ТА МІНЕРАЛЬНОГО СКЛАДУ КІСТКОВОЇ ТКАНИНИ НИЖНЬОЇ ЩЕЛЕПИ В НОРМІ, НА РІЗНИХ ТЕРМІНАХ ОПІОЇДНОГО ВПЛИВУ ТА ПІСЛЯ ТРАВМИ}

\author{
Масна 3. 3. \\ доктор медичних наук, професор, \\ завідувач кафедри оперативної хірургії з топографічною анатомією \\ Львівський національний медичний університет імені Данила Галицького \\ Согуйко P. P. \\ асистент кафедри оперативної хірургї̈ з топографічною анатомією \\ Львівський національний медичний університет імені Данила Галицького \\ Рудницька X. I. \\ кандидат медичних наук, \\ стариий викладач кафедри оперативної хірургії \\ з топографічною анатомією \\ Львівський національний медичний університет імені Данила Галищького
}

